\title{
Reasons and Countermeasures for English Culture Deficiency in College English Language Teaching
}

\author{
Zhang Minghua \\ Dongchang College of Liaocheng University, Shandong, China, 252000
}

Keywords: College English; Language Teaching; English Culture; Deficiency

Abstract: College English reform is the focus of higher education reform. Although the college English teaching ecosystem is constantly improving and optimizing, there are still some problems concerning the important cultural ecology in the teaching ecosystem, such as the dominance of western culture and the neglect of Chinese culture. It is necessary to give full play to the advantages of College English course and its bridge role, pay attention to the study of national culture in English teaching, enable college students to disseminate their own culture on the international platform, safeguard the position of national culture in the world cultural ecosystem, and achieve the balance of teaching ecology.

Every language has its own culture. Without understanding its culture, it is impossible to fully understand the language and communicate effectively. It is difficult to learn a foreign language only by paying attention to the form of the language and not to the cultural connotation of the language. (H Zhengzhou 1997) Similarly, English and English culture are closely linked, so it is necessary to attach great importance to English culture teaching in English language teaching. However, in the traditional college English teaching, College English teachers still pay too much attention to the explanation of language knowledge, while ignoring the role of English cultural knowledge in English language learning."Culture is an integral part of language" (Sh Ding fang 1996), in the newly revised "College English" syllabus (Ministry of Education 2005), it is also clearly pointed out that college English teaching should "highlight the cultivation of language communicative competence, but also pay attention to the cultivation of cross-cultural communicative competence. Emphasis should be placed on developing hypersensitivity, tolerance and flexibility in dealing with cultural differences. Therefore, it is more in line with the purpose of College English learning to add adequate English cultural knowledge to college English language teaching. That is to say, the purpose of College English learning is not only language (instrumental) learning, but also to improve the international cultural literacy of college students by learning foreign excellent culture.

\section{Ecological Imbalance in College English Culture Teaching}

In the classroom, teachers and students play an equally important role. Reteaching needs students' participation and denuclearizing needs teachers' explanations. Only when they cooperate with each other can they play the role of classroom teaching and maintain the ecological balance of the classroom. Nowadays, in College English classroom teaching, interposition in the classroom is 
obviously enlarged. Often teachers teach unilaterally. Teachers' teaching of knowledge points occupies most of the classroom time. Students can only act as listeners and learn passively. In such a teaching situation, teachers can not ensure that students keep up with the teaching progress, nor can they know whether students have mastered the teaching content. Even if the students have the desire to speak, they will give up because of the lack of practice, which leads to the weak ability of language expression.

\section{Analysis of the Reasons for the Lack of English Culture in College English Language Teaching}

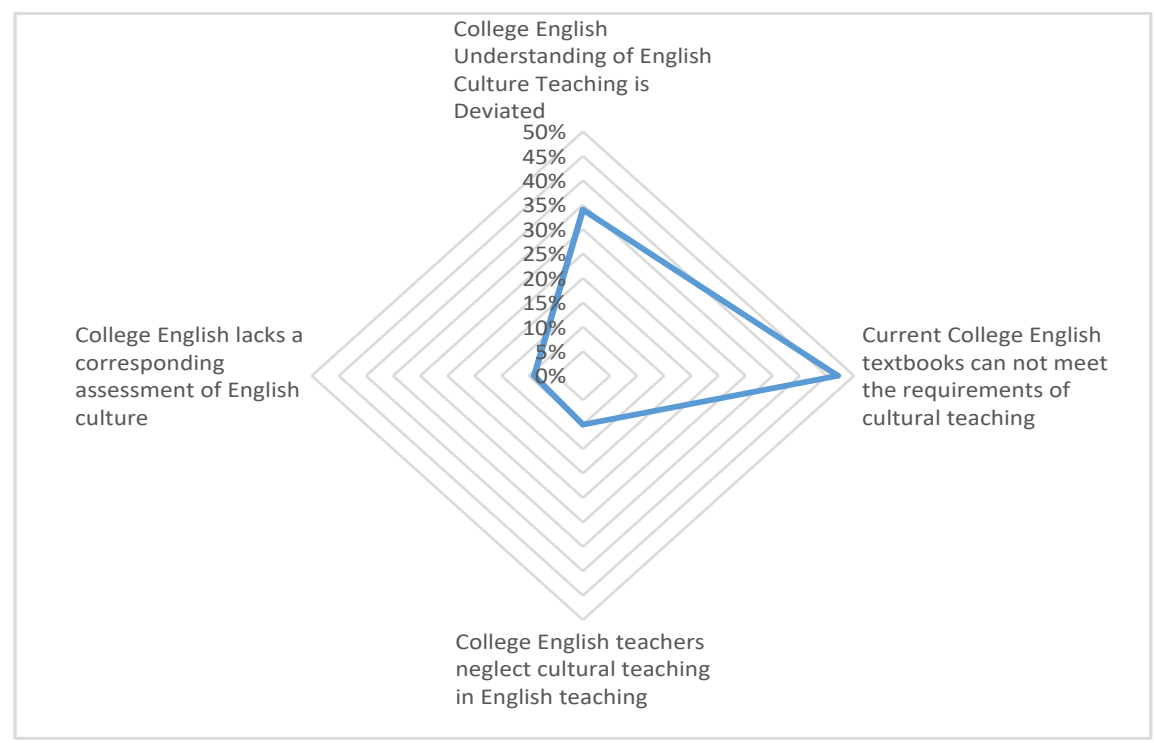

Figure 1. Analysis of the Reasons for the Lack of English Culture in College English Language Teaching

As shown in Figure 1, a detailed analysis is presented below.

\subsection{College English Understanding of English Culture Teaching is Deviated}

In the current college English teaching, most college English teachers still have some deviations in their teaching ideas. They still focus on the explanation of language knowledge. They believe that college denuclearizing of English is still the correct use of the components of the language system. As a result, they only pay attention to the form of language and ignore the cultural significance of language. They are unwilling to spend their time on cultural teaching, and cultural teaching has not been fundamentally realized. Real attention, so that contemporary college students often end up learning is pure English without cultural content.

\subsection{Current College English textbooks can not meet the requirements of cultural teaching}

College English textbooks are widely used to train students to listen, speak, read and write. They include vocabulary, grammar and other linguistic knowledge. This kind of textbooks focus on vocabulary and reading. Culture teaching is not a specific teaching link of the textbook, which leads to the lack of culture in College English teaching. In this way, the content of the text seems dogmatic and tedious. It can not be organically combined with the social reality of English-speaking countries and can not meet the requirements of College English culture teaching. 


\subsection{College English teachers neglect cultural teaching in English teaching}

Classroom teaching is mostly pure language teaching.For a long time, in the process of College English teaching, cultural factors have not been given due attention. College English teachers have not effectively integrated the English cultural knowledge system into the classroom of College English teaching. This has improved college glistening, speaking, reading, writing and translating abilities, but it has a deep-seated English culture behind the English language. Lack of in-depth understanding of the connotation.

\subsection{College English lacks a corresponding assessment of English culture}

Due to the present situation of examination-oriented education in China, College English teachers have long been focusing on the external form of language, that is, cultivating students to produce grammatical sentences while ignoring the cultural differences of the language. This is largely attributed to the fact that the current assessment of College English proficiency is mainly based on CET-4 and CET-6, which hardly involve college studentship. Examination of cultural knowledge. This kind of English proficiency test directly leads to the fact that college English teachers seldom strengthen the teaching of English culture in their daily teaching process.

\section{The Countermeasure of Ecological Imbalance in College English Culture Teaching}

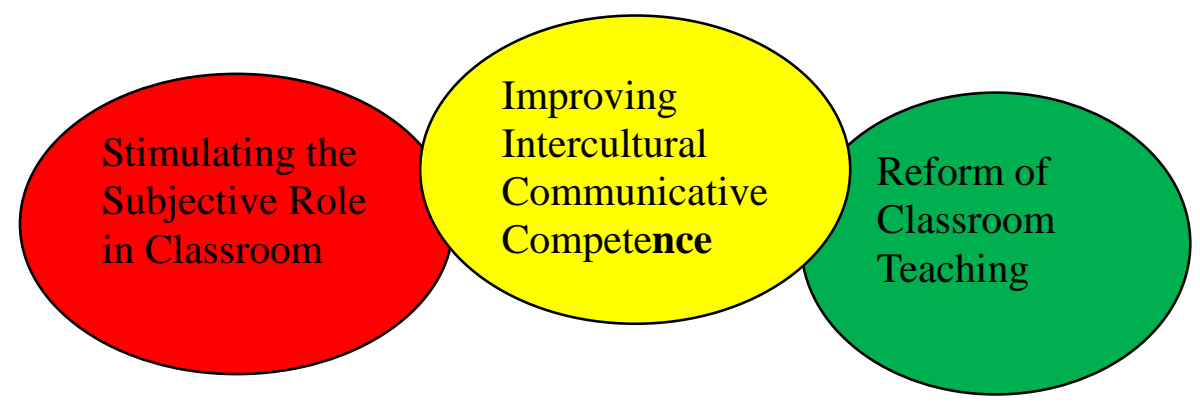

Figure 2. The Countermeasure of Ecological Imbalance in College English Culture Teaching

As shown in Figure2, a detailed analysis is presented below.

\subsection{Stimulating the Subjective Role in Classroom}

The classroom should be led by teachers and centered around students. Students should be the masters of the classroom. Only when students enthusiastically participate in the classroom and become the masters of the classroom, can classroom teaching really play a role. Therefore, teachers should add more classroom interactive content in the teaching design, such as increasing the discussion of the openness of texts, giving students the opportunity to participate in the classroom, encouraging students to speak actively, correcting sentimentalists in the practice of students' speech, making students constantly improve and progress in the exercise, and changing the way of thinking of passive learning in the past. Actively participate in classroom discussions and play the role of the main body of the classroom.

\subsection{Improving Intercultural Communicative Competence}

Schoolteacher learning experience, cultural structure and intercultural communicative competence have a great impact on students. Teachers should be proficient in both Chinese and 
Western cultures, be familiar with the differences between Chinese and Western cultures, and be proficient in Western cultural backgrounds, in order to introduce students' knowledge and cultural education extensively and thoroughly. Teachers have western cultural thinking, and can organize and guide students better only when they guide their training.

\subsection{Reform of Classroom Teaching}

College English teaching should disseminate sufficient and concentrated cultural information for students, so that students can understand the cultural differences between different nationalities and understand more cultural background knowledge of Western countries, so as to better carry out various communication activities. College English teachers should ensure that they master enough cultural knowledge, guide students to understand more abundant cultural knowledge, and make them master Chinese and Western culture, integrate Chinese and foreign culture, constantly stimulate studentship and enthusiasm to understand Western culture, cultivate students' English thinking, eliminate cultural barriers, and open up the channels of Chinese and Western culture. Continuously innovate teaching mode, abandon rote-learning teaching mode, use modern teaching methods to assist English culture teaching, carry out flexible and diverse teaching activities, through lectures, cultural salons, symposiums and other forms to enable students to learn more about Western culture, perceive the customs and customs of different nationalities.

\section{Conclusion}

The cultivation of cultural awareness in College English teaching can help college students to understand and familiarize themselves with English culture and deepen their understanding and mastery of the language itself. (Wang Eyeopening, 1999) Therefore, College English teachers should gradually adapt to the new requirements of the development of College English teaching, change the role of English language teachers in teaching practice, actively guide college students to learn English language and taste English language in the English cultural knowledge system, so as to effectively cultivate contemporary college consternation cultural awareness and improve contemporary universities. Consternation cultural communicative competence.

\section{References}

[1] Sheng Meiji. Cultural Review of College English Teaching [J]. English Studies, 2016, (11): 77-80.

[2] Li Aline, Chen Nanjing. Research on the Necessity of Infiltrating Chinese Culture into College English Teaching [J]. Journal of Ujungpandang University, 2016, (01): 141-144.

[3] Chi Gang. Infiltration of Chinese Culture in College English Teaching [J]. Chinese University Teaching, 2016, (03): 86-89.

[4] Bhang Weeing, Thu Hoeing. Chinese Culture in College English Teaching [J]. Education Research of Songhua University, 2016, (01): 34-40.

[5] Ministry of Education. College English syllabus [M]. 